\title{
ANALISIS PENGARUH INDIKATOR EKONOMI DAN KINERJA PERBANKAN SYARIAH TERHADAP PENYERAPAN TENAGA KERJA PADA PERBANKAN SYARIAH DI INDONESIA TAHUN 2008-2014)1)
}

\author{
Kurnia Sari Kasmiarno \\ Program Studi S1 Ekonomi Syariah-Fakultas Ekonomi dan Bisnis-Universitas Airlangga \\ Email: kasmiarnokurniasari@gmail.com \\ Karjadi Mintaroem \\ Departemen Ekonomi Syariah-Fakultas Ekonomi dan Bisnis-Universitas Airlangga \\ Email: mintaroem@yahoo.com
}

\begin{abstract}
:
This research aims to find out the relationship both simultaneosuly and partially of the eefect of PDB Real Bank, Syariah Banking Investment and the total of syariah banking financing towards the amount of employees in syariah banking. The approach used in this research is quantitative approach that uses multiple regression with Ordinary Least Square (OLS) method which has four variables that are PDB real bank, syariah banking investment and syariah banking financing as independent variables, meanwhile the amount of employees in syariah banking acts as a dependent variable. The result shows that all of the independent variables have positive/significant relationship towards the amount of employees in syariah banking in Indonesia between 2008-2014. . This shows that all of independent variables are able to explain the dependent variable accurately since the coefficient value obtained was high.
\end{abstract}

Keywords: PDB Real, investment, total of financing, islamic banking

\section{Pendahuluan}

Menurut Sukirno

(1985:14)

pembangunan ekonomi diartikan sebagai peningkatan pendapatan per kapita masyarakat (GDP) pada suatu tahun tertentu melebihi tingkat pertambahan penduduk, sedangkan pertumbuhan ekonomi adalah kenaikan dalam GDP tanpa memperhatikan tingkat pertambahan penduduk. Kualitas Pembangunan ekonomi terus menerus ditingkatkan oleh Indonesia dengan melakukan transformasi sistem ekonomi. Sejarah menjadi pembelajaran yang berharga bagi Indonesia, terutama kejadian krisis ekonomi pada tahun 19971998. Menurut Prasetyantoko (2008:210) faktor-faktor yang menyebabkan krisis di Indonesia semakin panjang adalah bidang mikro ekonomi, terutama prilaku sektor perbankan dan perusahaan yang pada waktu itu banyak melakukan aktivitas hutang. Dampak yang ditimbulkan dari krisis ini berupa nilai hutang perusahaan yang semakin pesat, selanjutnya akan menyebabkan banyak perbankan mengalami kebangkrutan, namun bank muamalat sebagai satusatunya bank yang menerapkan sistem syariah pada waktu itu ternyata bisa bertahan.

Kestabilan perbankan syariah membuat pelaku perbankan Indonesia tertarik untuk mendirikan bank dengan konsep kerja syariah. Perkembangan bank syariah terlihat pada tabel 1. di bawah ini: 
Kasmiarno, et al/Jurnal Ekonomi Syariah Teori dan Terapan Vol. 3 No. 10 Oktober 2016: 816-828; ANALISIS PENGARUH INDIKATOR EKONOMI DAN KINERJA PERBANKAN SYARIAH TERHADAP PENYERAPAN TENAGA KERJA PADA PERBANKAN SYARIAH DI INDONESIA TAHUN 2008-2014)

Tabel 1.

Jumlah Dana Pihak Ketiga dan Pembiayaan Perbankan Syariah (dalam juta rupiah)

\begin{tabular}{|c|c|c|c|c|}
\hline \multirow{2}{*}{$\begin{array}{c}\text { Tah } \\
\text { Un }\end{array}$} & \multicolumn{2}{|c|}{ DPK } & \multicolumn{2}{c|}{ Pembiayaan } \\
\cline { 2 - 5 } & $\begin{array}{c}\text { BUS dan } \\
\text { UUS }\end{array}$ & BPRS & $\begin{array}{c}\text { Bus dan } \\
\text { UUS }\end{array}$ & BPRS \\
\hline 200 & 52.271 .0 & 1.158. & 46.886 .0 & 1.586. \\
9 & 00 & 034 & 00 & 919 \\
\hline 201 & 76.036 .0 & 1.603. & 68.181 .0 & 2.060. \\
0 & 00 & 778 & 00 & 437 \\
\hline 201 & 115.415. & 2.095. & 102.655. & 2.675. \\
1 & 000 & 333 & 000 & 930 \\
\hline 201 & 147.512. & 2.937. & 147.505. & 3.553. \\
2 & 000 & 802 & 000 & 520 \\
\hline 201 & 242.276. & 2.984. & 184.122. & 4.433. \\
3 & 000 & 272 & 000 & 492 \\
\hline
\end{tabular}

Sumber : Statistik Perbankan Syariah 2013, diambil dari www.ojk.go.id diolah kembali

Menurut Kunt dan Harry (1998) dalam Stiawan (2009:15) untuk mengetahui kinerja internal suatu perbankan, maka digunakan variabel karakteristik bank yang didalamnya berisi rasio-rasio kevangan seperti total pembiayaan, aktivitas bank, dan lain-lain. Ketika kinerja internal suatu perbankan dalam lima tahun berturut-turut mengalami peningkatan, maka dapat dijadikan acuan bahwa perbankan syariah memiliki potensi untuk terus berkembang. Pendapat ini diperkuat Azwar (2015) yang menyatakan bahwa Indonesia dapat menjadi sebagai kiblat pengembangan industri keuangan syariah, hal ini dibuktikan oleh potensi dan peluang yang dimiliki negara ini yaitu: (1) jumlah penduduk muslim yang besar (2) pertumbuhan ekonomi yang tinggi antara
$6 \%-6,5 \%$ (3) peningkatan sovereign credit rating Indonesia (4) memiliki sumber daya alam yang melimpah yang dapat dijadikan sebagai underlying transaksi industri keuangan syariah (5) total aset keuangan syariah mencapai US\$20 miliar di tahun 2011. Perkembangan perbankan syariah tersebut harus diikuti dengan meningkatnya kualitas maupun kuantitas dalam penyerapan tenaga kerja sesuai pernyataan LPKS (2013) yaitu Sumber Daya Insani (SDI) merupakan faktor pendukung utama dalam pengembangan perbankan syariah sehingga diperlukan pemenuhan SDI baik kuantitas maupun kualitas untuk mendukung perluasan jaringan perbankan syariah yang telah menjangkau seluruh propinsi di Indonesia. Namun, hal ini berlainan dengan fakta yang ada, Alamsyah (2012:4-5) menunjukkan bahwa pemenuhan Sumber Daya Insani (SDI), baik secara kuantitas maupun kualitas merupakan tantangan untuk perbankan syariah melakukan perluasan usahanya, peningkatan ekspansi perbankan syariah tersebut ternyata tidak diimbangi oleh penyediaan Sumber Daya Insani (SDI) yang optimal, sehingga manfaatnya kurang dapat dirasakan, hal ini ditunjukkan dengan diperkirakan bahwa terjadi gap SDI sebanyak 20.000 orang. Opini tersebut didukung oleh pernyataan dari Budiawan (2014) selaku pengawas bank madya senior BI menyatakan bahwa seiring pertumbuhan perbankan syariah yang begitu pesat, maka kebutuhan akan 
Kasmiarno, et al/Jurnal Ekonomi Syariah Teori dan Terapan Vol. 3 No. 10 Oktober 2016: 816-828; ANALISIS PENGARUH INDIKATOR EKONOMI DAN KINERJA PERBANKAN SYARIAH TERHADAP PENYERAPAN TENAGA KERJA PADA PERBANKAN SYARIAH DI INDONESIA TAHUN 2008-2014)

tenaga kerja dibidang ini akan meningkat, setidaknya di tahun 2014 membutuhkan 9000 tenaga kerja, namun penyediaan tenaga kerja sebanyak itu tidak mungkin dengan mudah dilakukan oleh masingmasing bank, umumnya bank hanya mampu menyediakan sekitar 35 orang setiap tahunnya, sedangkan yang dibutuhkan jumlahnya ribuan. Masalah diatas perlu adanya perhatian yang serius, baik dari pihak dalam bank yang memegang faktor internal dalam kemajuan masing-masing perbankan syariah, maupun pihak luar seperti pemerintah, $\mathrm{Bl}$, dan OJK yang memegang faktor eksternal dalam kemajuan suatu perbankan syariah. Menurut Handoko (1985:3) dan Simanjuntak (1985:13) penyerapan tenaga kerja dipengaruhi oleh faktor eksternal berupa pertumbuhan ekonomi dan faktor internal berupa investasi dan nilai produksi. Pertumbuhan ekonomi diukur dengan menghitung PDB riil (Mankiw,2012:14), sementara investasi diartikan sebagai barang-barang modal, tanah, dan inventories (Salvatore, 1987:297), sedangkan nilai produksi dalam industri perbankan syariah menurut $\mathrm{BI}$ (2008) berupa pembiayaan, DPK, dan jasa-jasa lainnya.

Berdasarkan uraian yang telah dijelaskan, maka peneliti dapat merumuskan masalah penelitian sebagai berikut yaitu apakah PDB riil bank, investasi perbankan syariah, dan total pembiayaan perbankan syariah berpengaruh baik secara parsial maupun simultan terhadap jumlah pekerja pada perbankan syariah di
Indonesia tahun 2008-2014. Adapun tujuan penelitian ini adalah untuk menganalisis pengaruh variabel PDB rill bank, investasi perbankan syariah, dan total pembiayaan perbakan syariah baik secara simultan maupun parsial terhadap jumlah pekerja pada perbankan syariah di Indonesia tahun 2008-2014.

\section{Landasan teori}

Menurut Simanjuntak (1998:12) dan Handoko (1985:38) penyerapan tenaga kerja dipengaruhi oleh faktor internal dan faktor eksternal dari tiap-tiap unit usahanya. Secara internal dipengaruh oleh investasi rill dan nilai produksi, sedangkan secara eksternal dipengaruhi oleh pertumbuhan ekonomi.

Menurut Mankiew (2012:14) cara untuk mengetahui pertumbuhan ekonomi yaitu dengan mengetahui PDB riil, sehingga kebutuhan akan jumlah pekerja pada perbankan syariah dapat dilihat dari variabel PDB riil bank. Ketika perekonomian sedang mundur (PDB riil rendah) maka keinginan untuk melakukan konsumsi akan berkurang, sehingga menyebabkan stok-stok barang dalam perusahaan bertambah. Keadaan ini menyebabkan perusahaan mengurangi aktivitas produksi dan mengurangi penggunaan tenaga kerja.

Selain PDB riil, investasi perbankan syariah juga mempengaruhi keputusan perbankan untuk menambah jumlah pekerjanya. Samuelson menjelaskan pengertian investasi sebagai berikut "investment (or purchase of capital goods) consists of the additions to the 
Kasmiarno, et al/Jurnal Ekonomi Syariah Teori dan Terapan Vol. 3 No. 10 Oktober 2016: 816-828; ANALISIS PENGARUH INDIKATOR EKONOMI DAN KINERJA PERBANKAN SYARIAH TERHADAP PENYERAPAN TENAGA KERJA PADA PERBANKAN SYARIAH DI INDONESIA TAHUN 2008-2014)

nation's capital stock of buildings, equipment, and inventories during a year". ketika tingkat investasi tahun sebelumnya meningkat maka barangbarang modal akan bertambah, sehingga diperlukan tenaga kerja sebagai pengendali aktiva tetap perusahaan tersebut. Hal ini didukung oleh pendapat Simanjuntak (1998:153) yang menyatakan bahwa perkiraan daya serap tenaga kerja tiap sektor ekonomi diukur berdasarkan satuan pertambahan investasi untuk penciptaan satu kesempatan kerja pada waktu yang lalu, perkiraan incremental capital-employment ration dan labor requirement perunit output untuk jangka waktu perencanaan, dan rencana investasi.

Variabel selanjutnya yang mempengaruhi keputusan perbankan terkait menambah atau mengurangi jumlah pekerjanya yaitu nilai produksi. Sumarsono (2003:69-70) mengungkapkan definisi nilai produksi sebagai tingkat produksi atau keseluruhan jumlah barang yang merupakan hasil akhir proses produksi pada unit usaha tertentu, ketika permintaan pasar akan hasil produksi dari perusahaan yang bersangkutan mengalami kenaikan atau penurunan, maka produsen cenderung untuk menambah kapasitas, sehingga produsen juga akan menambah penggunaan tenaga kerjanya. Menurut BI (2008) perbankan syariah mengeluarkan hasil akhir produksi berupa produk-produk perbankan syariah yang terdiri atas produk penghimpunan dana, produk penyaluran dana, dan produk jasa.

Pendapatan yang diterima bank syariah dari pembiayaan bagi hasil besarnya ditentukan oleh tingkat margin dan nisbah bagi hasil antara bank dan nasabah. Pendapatan bank merupakan salah satu faktor penting dalam pembiayaan karena besar kecilnya pendapatan akan menentukan besar kecilnya pembiayaan yang disalurkan oleh bank. Sedikit demi sedikit bank syariah mengalami pertumbuhan meskipun tidak berkembang secara cepat. Perkembangan bank syariah dapat dilihat dari peningkatan jumlah pembiayaan bagi hasil yang dilakukan bank syariah. Peningkatan jumlah pembiayaan bagi hasil disebabkan oleh semakin banyaknya nasabah yang berminat untuk menghimpun dananya di bank syariah, sehingga bank semakin gencar melakukan pembiayaan. Pengalokasian dana yang diwujudkan dalam bentuk pembiayaan maupun pembelian aset dapat menghasilkan keuntungan bagi perbankan syriah, selisih antara bagi hasil yang diterima dari alokasi dana tertentu tersebut merupakan keuntungan utama bagi bisnis perbankan syariah.

\section{Metode Penelitian}

Pendekatan penelitian yang digunakan dalam penelitian ini adalah pendekatan kuantitatif dengan menggunakan model panel atau pooled data yang merupakan kombinasi dari data time series dan cross section. 
Kasmiarno, et al/Jurnal Ekonomi Syariah Teori dan Terapan Vol. 3 No. 10 Oktober 2016: 816-828; ANALISIS PENGARUH INDIKATOR EKONOMI DAN KINERJA PERBANKAN SYARIAH TERHADAP PENYERAPAN TENAGA KERJA PADA PERBANKAN SYARIAH DI INDONESIA TAHUN 2008-2014)

Pengujian dilakukan dengan signfikasi hubungan antar variabel dengan uji T dan uji F. Kedua uji tersebut digunakan untuk mengetahui signifikasi perhitungan model analisis yang digunakan. Pengujian model analisis juga menghasilkan koefisien determinasi mejemuk $\left(R^{2}\right)$ serta nilai koefisien $\beta$ yang menunjukkan seberapa besar pengaruh masing-masing variabel bebas terhadap variabel terikat.

\section{Definisi operasional}

1. PDB riil bank

PDB riil bank merupakan PDB yang berada pada sub sektor industri jasa dan keuangan yang mempengaruhi penyerapan pekerja pada perbankan syariah tahun kerja $n$ adalah PDB riil tahun $\mathrm{n}$.

2. Investasi Perbankan Syariah

Nilai investasi yang dimasukkan dalam penelitian ini adalah persediaan barang modal yang terdiri dari pabrik, mesin-mesin kantor, dan produkproduk tahan lama lainnya yang digunakan dalam proses produksi yang tercantum di neraca sebagai aktiva tetap dan inventories. Investasi perbankan syariah yang mempengaruhi perubahan jumlah pekerja pada tahun $\mathrm{n}$ adalah jumlah aktiva tetap dan inventories pada tahun $\mathrm{n}$.

3. Total pembiayaan pada perbankan syariah

Total pembiayaan merupakan produk perbankan syariah berupa penyaluran dana kepada masyarakat. Total pembiayaan perbankan syariah yang mempengaruhi perubahan jumlah pekerja pada tahun $\mathrm{n}$ adalah jumlah total pembiayaan perbankan syariah pada tahun $\mathrm{n}$.

4. Jumlah pekerja pada perbankan syariah

Jumlah pekerja pada perbankan syariah merupakan karyawan yang telah bekerja pada Perbankan Syariah pada tahun 2008-2014. Jumlah tersebut diperoleh dari penambahan banyaknya pekerja laki-laki dan pekerja perempuan.

\section{Jenis dan Sumber Data}

Jenis data dalam penelitian ini merupakan data sekunder. Data time series yang digunakan merupakan data tahunan selama tujuh tahun penelitian, yaitu tahun 2008-2014. Data cross section yang digunakan merupakan data sampel yang terdiri atas Bank Umum Syarah (BUS), Bank Pembiayaan Rakyat Syariah (BPRS), dan Unit Usaha Syariah (UUS), dimana BUS digabung dengan UUS sesuai ketentuan yang berlaku di neraca yang ditampilkan oleh OJK dan BI.

\section{Prosedur Pengumpulan Data}

Prosedur pengumpulan data dilaksankan dengan metode dokumenter, artinya data yang diperlukan dalam penelitian ini adalah data sekunder yang telah didokumentasi oleh instansi atau dinas terkait (OJK, BPS, dan BI).

\section{Teknik Analisis Data}

Penelitian ini menggunakan teknik analisis regresi data panel. Terdapat beberapa keuntungan dari penggunaan 
Kasmiarno, et al/Jurnal Ekonomi Syariah Teori dan Terapan Vol. 3 No. 10 Oktober 2016: 816-828; ANALISIS PENGARUH INDIKATOR EKONOMI DAN KINERJA PERBANKAN SYARIAH TERHADAP PENYERAPAN TENAGA KERJA PADA PERBANKAN SYARIAH DI INDONESIA TAHUN 2008-2014)

data panel dalam penelitian, menurut Gujarati (2012:237) yaitu memberikan lebih banyak informasi, variasi, keefisienan dan mempunyai sedikit kolinearitas antar variabel dan cocok digunakan untuk mempelajari dinamika perubahan seperti tingkat pengangguran, perputaran pekerjaan, dan mobilitas tenaga kerja. Data panel pada penelitian ini menggunakan panel seimbang dan panel panjang. Panel panjang terjadi jika jumlah data time series (T) lebih besar daripada data cross section (N).

Menurut Widarjono (2005:252-256) ada tiga kemungkinan teknik estimasi. Keterangan lebih lanjut adalah sebagai berikut :

1. Model OLS pooled adalah model untuk mengestimasi data panel tanpa melihat adanya perbedaan diantara waktu dan individu.

2. Fixed Effect Model (FEM) mengasumsikan bahwa prilaku antar subjek atau cross section berbeda dalam kurun waktu yang sama, atau dikatakan memiliki heterogenitas antarsubjek dengan memberi setiap entitas nilai intersep tersendiri. Teknik model ini mengestimasi data panel dengan menggunakan variabel dummy.

3. Random Effect Model (REM) yaitu mengestimasi data panel dimana variabel gangguan (error terms) mungkin saling berhubungan antar waktu dan antar individu.

Uji asumsi klasik tidak diperlukan dalam analisis data panel karena data panel dapat meminimlakan bias yang kemungkinan besar muncul dalam hasil analisis, memberi lebih banyak informasi, variasi, dan degree of freedom (Gujarati, 2012:237). Keunggulan-keunggulan data panel menyebabkan data panel mampu mendeteksi dan mengukur dampak dengan lebih baik dimana hal ini tidak bisa dilakukan dengan metode cross section maupun time series. Panel data memungkinkan mempelajari lebih kompleks mengenai prilaku yang ada dalam model sehingga pengujian data panel tidak memerlukan uji asumsi klasik (Gujarati 1992 dalam Iswanto (2013)).

Cara untuk menentukan pemilihan model diantara PLS atau FEM di Eviews 8 yaitu dengan melihat Redundant Fixed Effect Test, apabila hasil nilai Fhitung $<$ Ftabel atau P-value signifikan pada tingkat keyakinan (a) tertentu maka kita menerima hipotesis Ho sehingga kita harus menggunakan PLS. Jika teknik yang terpilih yaitu PLS, maka menurut Ariefianto (2012:152) dalam meningkatkan kualitas hasil estimasi, maka kita dapat mengubah parameter yang ada pada panel option di equation window dari metode Pooled Least Squares weight menjadi metode Pooled EGLS (cross-section weight). Namun, apabila hasil nilai Fhitung $>$ Ftabel atau P-value signifikan pada tingkat keyakinan (a) tertentu maka kita menolak hipotesis $\mathrm{H}_{0}$ sehingga kita menerima hiotesis $H_{1}$ yang menyatakan kita harus menggunakan FEM untuk teknik estimasi dalam penelitian ini, sehinggatahap selanjutnya adalah melakukan Uji 
Kasmiarno, et al/Jurnal Ekonomi Syariah Teori dan Terapan Vol. 3 No. 10 Oktober 2016: 816-828; ANALISIS PENGARUH INDIKATOR EKONOMI DAN KINERJA PERBANKAN SYARIAH TERHADAP PENYERAPAN TENAGA KERJA PADA PERBANKAN SYARIAH DI INDONESIA TAHUN 2008-2014)

Hausman untuk memilih antara Fixed Effect (FEM) dan Random Effect (REM)

\section{Hasil dan Pembahasan}

Penelitian ini bertujuan untuk menganalisis pengaruh PDB riil bank, investasi perbankan syariah, dan total pembiayaan perbankan syariah terhadap jumlah pekerja pada perbankan syariah di Indonesia tahun 2008-2014. Berdasarkan teknik estimasinya, model regresi dengan data panel dapat diestimasi menggunakan tiga metode estimasi yaitu PLS, FEM, ataupun REM

\section{Pemilihan Model Estimasi}

Tabel 2.

Uji Redundant Fixed Effect Test

\begin{tabular}{|l|l|l|l|}
\hline \multicolumn{4}{|l|}{ Redundant Fixed Effect Tests } \\
\hline \multicolumn{2}{|l|}{ Pool : Untitled } \\
\hline Test cross-section fixed effect \\
\hline Effect Test & Statistics & d.f. & Prob \\
\hline $\begin{array}{l}\text { Cross- } \\
\text { section F }\end{array}$ & 0,569929 & $(1,9)$ & 0,4696 \\
\hline
\end{tabular}

Sumber : Hasil Perhitungan Regresi

. Pada tabel 2. diatas ditunjukkan nilai probabilitas sebesar 0,4696 sehingga nilai probabilitas lebih besar dari $a=5 \%$ dimana $\mathrm{H}_{0}$ diterima, artinya teknik estimasi yang baik digunakan dalam penelitian ini adalah model Pooled Least Square (PLS). Karena yang terpilih adalah teknik estimasi dengan uji PLS maka tahap Uji Hausman yang digunakan untuk memilih antara metode FEM atau REM dalam penelitian tidak perlu lagi untuk dilakukan.

\section{Identifikasi Hasil Estimasi Persamaan Regresi Data Panel}

Tabel 3.

Hasil Regresi Data Panel dengan Metode Pooled EGLS (Cross Section Weight)

\begin{tabular}{|c|c|c|c|c|}
\hline Var & Coeff. & $\begin{array}{l}\text { Std. } \\
\text { Error }\end{array}$ & t-Stat & Prob \\
\hline PDB_RIIL & $\begin{array}{l}3,67 \mathrm{E}- \\
05\end{array}$ & $\begin{array}{l}1,07 \mathrm{E}- \\
05\end{array}$ & $\begin{array}{l}3,4253 \\
90\end{array}$ & $\begin{array}{l}0,00 \\
65\end{array}$ \\
\hline INVEST & $\begin{array}{l}0,0036 \\
60\end{array}$ & $\begin{array}{l}0,0014 \\
69\end{array}$ & $\begin{array}{l}2,4913 \\
53\end{array}$ & $\begin{array}{l}0,03 \\
19\end{array}$ \\
\hline $\begin{array}{l}\text { TOTAL_C } \\
\text { ost }\end{array}$ & $\begin{array}{l}0,0001 \\
41\end{array}$ & $\begin{array}{l}2,14 \mathrm{E}- \\
05\end{array}$ & $\begin{array}{l}6,5947 \\
90\end{array}$ & $\begin{array}{l}0,00 \\
01\end{array}$ \\
\hline C & $\begin{array}{l}- \\
617,38 \\
86\end{array}$ & $\begin{array}{l}1048,6 \\
45\end{array}$ & $\begin{array}{l}- \\
0,5887 \\
49\end{array}$ & $\begin{array}{l}0,56 \\
91\end{array}$ \\
\hline \multicolumn{5}{|c|}{ Weighted Statistics } \\
\hline $\begin{array}{l}\text { R- } \\
\text { squared }\end{array}$ & $\begin{array}{l}0,9935 \\
34\end{array}$ & \multicolumn{2}{|c|}{$\begin{array}{l}\text { Mean } \\
\text { dependent } \\
\text { var }\end{array}$} & $\begin{array}{l}15364, \\
45\end{array}$ \\
\hline $\begin{array}{l}\text { F- } \\
\text { statistic }\end{array}$ & $\begin{array}{l}512,17 \\
04\end{array}$ & \multicolumn{2}{|c|}{$\begin{array}{l}\text { Durbin- } \\
\text { Watson stat }\end{array}$} & $\begin{array}{l}2,2650 \\
33\end{array}$ \\
\hline $\begin{array}{l}\text { Prob(F- } \\
\text { statistic) }\end{array}$ & $\begin{array}{l}0,0000 \\
00\end{array}$ & & & \\
\hline
\end{tabular}

Sumber : Hasil Perhitungan Regresi

Tabel 3. diatas, menunjukkan hasil estimasi dengan metode Pooled EGLS (cross-section weight), hasilnya menunjukkan bahwa model ini signifikan dalam uji $F$ (koefisien simultan) dengan tingkat kesalahan mendekati 0\%. Kinerja model tersebut juga cukup baik, yaitu dengan nilai dari $\mathrm{R}^{2}$ (koefisien determinasi) adalah sebesar 99,35\% dan nilai Adjusted $\mathrm{R}^{2}$ (koefisien determinasi adjusted) adalah sebesar $99,20 \%$.

Uji F

Uji F-statistik pada penelitian ini menunjukkan nilai probabilitas kesalahan 0,000000 dimana lebih kecil dari tingkat kepercayaan sebesar 0,05 atau 5\%, Dari hasil ini dapat disimpulkan bahwa variabel bebas yang dimaksudkan dalam model penelitian, yaitu jumlah PDB riil bank, investasi perbankan syariah, dan total pembiayaan perbankan syariah secara simultan memiliki pengaruh yang signifikan terhadap variabel terikat yaitu jumlah 
Kasmiarno, et al/Jurnal Ekonomi Syariah Teori dan Terapan Vol. 3 No. 10 Oktober 2016: 816-828; ANALISIS PENGARUH INDIKATOR EKONOMI DAN KINERJA PERBANKAN SYARIAH TERHADAP PENYERAPAN TENAGA KERJA PADA PERBANKAN SYARIAH DI INDONESIA TAHUN 2008-2014)

pekerja pada perbankan syariah di Indonesia tahun 2008-2014.

\section{Uji T}

Tabel 4.

Hail Uji † (Koefisien Parsial)

\begin{tabular}{|l|l|l|}
\hline Variabel Bebas & $\begin{array}{l}\text { Prob.t- } \\
\text { statistik }\end{array}$ & Signifikansi \\
\hline PDB Riil Bank & 0,0065 & $\begin{array}{l}\text { Signifikan } \\
\mathrm{a}=5 \%\end{array}$ \\
\hline $\begin{array}{l}\text { Investasi } \\
\text { Perbankan } \\
\text { Syariah }\end{array}$ & 0,0319 & $\begin{array}{l}\text { Signifikan } \\
\mathrm{a}=5 \%\end{array}$ \\
\hline $\begin{array}{l}\text { Total } \\
\text { Pembiayaan } \\
\text { Perbankan } \\
\text { Syariah }\end{array}$ & 0,0001 & $\begin{array}{l}\text { Signifikan } \\
\mathrm{a}=5 \%\end{array}$ \\
\hline
\end{tabular}

Sumber : Hasil Perhitungan Regresi

1. Koefisien variabel PDB riil bank mempunyai nilai probabilitas t-hitung sebesar 0,0065. Angka ini menunjukkan nilai probabilitas t-hitung kurang dari level of significance $(a=0,05)$, sehingga $\mathrm{H}_{0}$ ditolak dan $\mathrm{H}_{1}$ diterima yang berarti kondisi PDB riil bank secara parsial berpengaruh terhadap jumlah pekerja pada perbankan syariah di Indonesia tahun 2008-2014.

2. Koefisien variabel nilai investasi perbankan syariah mempunyai nilai probabilitas t-hitung sebesar 0,0319. Angka ini menunjukkan nilai probabilitas t-hitung kurang dari level of significance $(a=0,05)$, sehingga sehingga $\mathrm{H}_{0}$ ditolak dan $\mathrm{H}_{1}$ diterima yang berarti kondisi investasi perbankan syariah secara parsial berpengaruh terhadap jumlah pekerja pada perbankan syariah di Indonesia tahun 2008-2014.
3. Koefisien variabel total pembiayaan perbankan syariahmempunyai nilai probabilitas t-hitung sebesar 0,0001. Angka ini menunjukkan nilai probabilitas t-hitung kurang dari level of significance $(a=0,05)$, sehingga sehingga $\mathrm{H}_{0}$ ditolak dan $\mathrm{H}_{1}$ diterima yang berarti kondisi Total Pembiayaan perbankan syariah secara parsial berpengaruh terhadap jumlah pekerja pada perbankan syariah di Indonesia tahun 2008-2014.

\section{Uji Koefisien Determinansi $\left(\mathbf{R}^{2}\right)$}

Pada hasil regresi data panel diperoleh koefisien determinasi $\left(R^{2}\right)$ yang menunjukkan kemampuan variasi variabel bebas (independent variable) secara bersama-sama dalam menjelaskan variabel terikat (dependent variable). Angka $R^{2}$ yang dieroleh sangat tinggi, yaitu sebesar 0,993534 atau sebesar $99,35 \%$.

\section{Pembahasan}

Angka koefisien determinasi yang ditunjukkan dalam hasil pengolahan data ini sangatlah tinggi, hal ini menunjukkan bahwa ketiga variabel bebas sangat akurat untuk menjelaskan variabel terikat yang ada.Variabel-variabel pendukung lain yang tidak dimasukkan dalam model atau berada di luar model penelitian (error term) kemungkinan dapat dijelaskan oleh variabel jumlah perusahaan yang relevan dengan penelitian yang pernah dilakukan Putra (2013), hasil penelitiannya membuktikan bahwa jumlah perusahaan memiliki pengaruh positif atau signifikan terhadap penyerapan tenaga kerja di 
Kasmiarno, et al/Jurnal Ekonomi Syariah Teori dan Terapan Vol. 3 No. 10 Oktober 2016: 816-828; ANALISIS PENGARUH INDIKATOR EKONOMI DAN KINERJA PERBANKAN SYARIAH TERHADAP PENYERAPAN TENAGA KERJA PADA PERBANKAN SYARIAH DI INDONESIA TAHUN 2008-2014)

industri kecil yang ada di kota Madiun. Dumairy (1996:228) dalam Putra (2013:41)menjelaskan teori industrialisasi yang menyatakan bahwa munculnya industri-industri baru, baik melalui pemenuhan kebutuhan barang atau jasa, pada akhirnya akan berdampak terhadap peningkatan kemakmuran, kesejahterahan, dan penyerapan tenaga kerja. Selain variabel jumlah perusahaan, kemungkinan variabel lain yang mampu menjelaskan jumlah pekerja pada perbankan syariah yaitu variabel upah yang relevan dengan dengan penelitian yang dilakukan Ferdinan (2011) dan Fahmi (2008) yang membuktikan bahwa variabel nilai upah memiliki pengaruh yang positif atau signifikan terhadap penyerapan tenaga kerja di Sumatera Barat dan Aceh.

Berdasarkanpadaperhitunganhasilr egresi model panel dalampenelitian yang dilakukan, maka dapat dianalisis secara simultan bahwa variable mempunyai pengaruh yang positif atau signifikan terhadap variable terikat. Hal ini menjadikan ketiga variabel ini memiliki pengaruh kuat terhadap kondisi perkembangan jumlah pekerja di perbankan syariah.Semua variabel bebas secara parsial juga memiliki pengaruh yang positif atau signifikan terhadap variabel terikat.

Pengaruh PDB riil Bank terhadap jumlah pekerja di perbankan syariah

Variabel PDB riil bank secaraparsialmempunyaipengaruhsignifik anterhadapjumlahpekerjapadaperbanka nsyariah di Indonesia tahun 2008-2014. PDB riiltentunyamemegangperananpentingdal amperkembanganjumlahpekerjapadasua tuindustri. Okun(1980)dalam Mankiew (2012)menjelaskanbahwa ketika PDB naik maka pengangguran akan turun. Hal ini memberi kesimpulan bahwa terdapat pengaruh diantara PDB riil terhadap perkembangan jumlah pekerja. Hasil penelitian ini juga relevan dengan penelitian yang dilakukan Wahyudiantoro (2010), Ferdinan (2011), dan Fahmi (2008) yang menyatakan bahwa variabel PDB memiliki pengaruh yang positif atau signifikan terhadap penyerapan tenaga kerja.

\section{Pengaruh Invetasi Perbankan Syariah Terhadap Jumlah Pekerja di Perbankan Syariah}

Terdapat hubungan antara investasi langsung yang dilakukan oleh perbankan syariah terhadap perkembangan jumlah pekerja yang dibutuhkan. Bertambahnya jumlah investasi langsung yang dilakukan oleh perbankan syariah berupa penambahan aset tetap berwujud yang bertujuan untuk kepentingan perusahaan dapat meningkatkan kebutuhan perusahaan akan perekrutan pekerja. Suparmoko (2002:264-265) dalam teorinya menyatakan bahwa besarnya nilai investasi akan menentukan besarnya kebutuhan akan pekerja di suatu industri. Maksud yang dapat disimpulkan yaitu bahwa semakin besar nilai investasi yang dilakukan maka semakin besar pula pekerja yang dibutuhkan. 
Kasmiarno, et al/Jurnal Ekonomi Syariah Teori dan Terapan Vol. 3 No. 10 Oktober 2016: 816-828; ANALISIS PENGARUH INDIKATOR EKONOMI DAN KINERJA PERBANKAN SYARIAH TERHADAP PENYERAPAN TENAGA KERJA PADA PERBANKAN SYARIAH DI INDONESIA TAHUN 2008-2014)

Investasi memegang peranan vital bagi setiap industri, karena investasi menimbulkan peluang bagi para pelaku usaha untuk melakukan ekspansi atas usahanya, sehingga dapat meningkatkan output yang secara tidak langsung berdampak pada peningkatan kebutuhan akan pekerja. Hasil penelitian ini juga relevan dengan penelitian yang dilakukan Putra (2012), Putra (2013), dan Fahmi (2008) yang menyatakan bahwa variabel investasi memiliki pengaruh yang positif atau signifikan terhadap penyerapan tenaga kerja.

Hubungan yang bernilai positif ini juga sesuai dengan teori yang diungkapkan Simanjuntak (1998:153) yang menyatakan bahwa perkiraan daya serap tenaga kerja tiap sektor dan sub sektor ekonomi diukur berdasarkan satuan pertambahan investasi untuk penciptaansatu kesempatan kerja pada waktu yang lalu, perkiraan incremental capital-employment ration dan labor requirement perunit output untuk jangka waktu perencanaan, dan rencana investasi. Artinya, ketika tingkat investasi tahun sebelumnya meningkat maka barang-barang modal akan bertambah, sehingga diperlukan tenaga kerja sebagai pengendali aktiva tetap perusahaan tersebut. Secara umum dapat disimpulkan bahwa semakin meningkatnya nilai investasi perbankan syariah di Indonesia, maka semakin meningkat pula jumlah pekerja pada perbankan syariah tersebut.
Pengaruh Total Pembiayaan Perbankan Syariah Terhadap Jumlah Pekerja Pada Perbankan Syariah

Variabel Total Pembiayaan secara parsial mempunyai pengaruh signifikan terhadap jumlah pekerja pada perbankan syariah di Indonesia tahun 2008-2014. Naik turunnya permintaan pasar akan hasil produksi dari perbankan yang bersangkutan ini sangat mempengaruhi perkembangan jumlah pekerjanya. Sesuai dengan teori "derived demand" yang menyatakan bahwa pertambahan permintaan suatu industri terhadap tenaga kerja bergantung dari pertambahan permintaan masyarakat akan barang dan jasa yang diproduksi suatu industri tersebut.

Sumarsono (2003:69) memperkuat eksistensi hubungan dari teori permintaan hasil produksi dengan pertambahan jumlah pekerja, dimana apabila permintaan hasil produksi perusahaan atau industri meningkat, produsen cenderung untuk menambah kapasitas produksinta, maka dengan begitu produsen akan menambah penggunaan tenaga kerjanya atau dengan kata lain akan terjadi pertambahan jumlah pekerja. Teori Simanjuntak (1998:87) juga menyatakan bahwa pengusaha mempekerjakan seseorang karena akan membantu proses produksi barang atau jasa untuk dijual kepada konsumen. Sehingga, dapat disimpulkan bahwa kenaikan permintaan pengusaha terhadap pekerja, tergantung dari kenaikan permintaan masyarakat akan 
Kasmiarno, et al/Jurnal Ekonomi Syariah Teori dan Terapan Vol. 3 No. 10 Oktober 2016: 816-828; ANALISIS PENGARUH INDIKATOR EKONOMI DAN KINERJA PERBANKAN SYARIAH TERHADAP PENYERAPAN TENAGA KERJA PADA PERBANKAN SYARIAH DI INDONESIA TAHUN 2008-2014)

barang yang diproduksi industri atau perusahaan tersebut.

Total pembiayaan menunjukkan nilai produksi suatu perbankan syariah, apabila total pembiayaan meningkat, maka nilai produksi suatu perbankan syariah itu ikut meningkat. Hubungan antara nilai produksi dengan perkembangan jumlah pekerja di perbankan syariah yang bernilai positif ini juga relevan dengan dengan penelitian yang dilakukan oleh Woyanti (2009). Hasil perhitungan model estimasi tersebut secara teoritispun dapat diterima, dimana sesuai dengan teori yang diungkapkan oleh Simanjuntak (1998:85) yang menyatakan bahwa semakin tinggi jumlah barang atau jasa yang diminta oleh konsumen (pasar), maka produsen akan menambah kapasitas produksinya, dengan demikian produsen akan membutuhkan pekerja yang lebih banyak

\section{Simpulan}

Berdasarkan pada nilai analisis dan pengujian hipotesis, maka dapat diambil kesimpulan sebagai berikut bahwa variabel bebas berupa PDB riil bank, investasi perbankan syariah, dan total pembiayaan perbankan syariah baik secara simultan maupun parsial berpengaruh terhadap jumlah pekerja pada perbankan syariah di Indonesia tahun 2008-2014.

Variabel bebas yang pertama yaitu PDB riil berpengaruh terhadap variabel terikatkarena sesuai dengan teori pokok gelombang perusahaan, ketika PDB Riil bank naik maka aktivitas produksi perbankan tersebut akan meningkat sehingga perusahaan akan menambah jumlah pekerjanya, sedangkan pengaruh variabel bebas kedua yaitu investasi terjadi ketika tingkat investasi langsung tahun sebelumnya meningkat maka akan menyebabkan pertambahan aset tetap dan inventories yang memerlukan orang yang mengendalikannya sehingga kebutuhan akan pekerja pada perbankan syariah ikut meningkat. Pengaruh variabel bebas yang ketiga terhadap variabel terikat yaitu total pembiayaan ditunjukkan apabila total pembiayaan meningkat, maka nilai produksi suatu perbankan syariah itu ikut meningkat sehingga sesuai dengan teori Simanjuntak (1998:87) yang menyatakan bahwa pengusaha mempekerjakan seseorang karena akan membantu proses produksi barang atau jasa untuk dijual kepada konsumen, oleh karena itu dapat disimpulkan bahwa kenaikan permintaan pengusaha terhadap pekerja, tergantung dari kenaikan permintaan masyarakat akan barang yang diproduksi industri atau perusahaan tersebut.

\section{DAFTAR PUSTAKA}

Alamsyah, Halim. 2012. Perkembangan dan Prospek Perbankan Syariah Indonesia : Tantangan dalam Menyongsong MEA 2015, (online), http://www.bi.go.id/id/ruangmedia/pidato-dewangubernur/Pag, diakses pada tanggal 13 maret 2016. 
Kasmiarno, et al/Jurnal Ekonomi Syariah Teori dan Terapan Vol. 3 No. 10 Oktober 2016: 816-828; ANALISIS PENGARUH INDIKATOR EKONOMI DAN KINERJA PERBANKAN SYARIAH TERHADAP PENYERAPAN TENAGA KERJA PADA PERBANKAN SYARIAH DI INDONESIA TAHUN 2008-2014)

Ariefianto, Moch. Doddy. 2012.

Ekonometrika: Esensi dan Aplikasi dengan Menggunakan Eviews. Jakarta: Penerbit Erlangga.

Azwar. 2015. Industri Perbankan Syariah Menghadapi Masyarakat Ekonomi Asean (MEA) 2015 : Peluang dan Tantangan Kontemporer, Artikel Badan Diklat Kevangan (BDK), (online), (www.bppk.kemenkeu.go.id, diakses pada tanggal 15 Januari 2015.

Bank Indonesia. 2008. Kodifikasi Produk Perbankan Syariah, (online), www.bi.go.id, diakses pada tanggal 12 Desember 2015

Budiawan, Bambang w. 2014. Bank Syariah Butuh 9000 Tenaga kerja, (online),

(http://www.syariahmandiri.co.id/2010/

12/bank-syariah-butuh-9-000-tenagakerja/),

Gujarati, Damodar. 2012. Dasar-Dasar Ekonometrika. Jakarta:Salemba Empat, diakses tanggal 13 Maret 2016.

Fahmi, Moch Nashiruddin. 2008. Analisis Penyerapan Tenaga Kerja di Sumatera dan Fakta-Fakta yang Mempengaruhinya Tahun 2002-2006 (Studi Kasus Bencana Tsunami). Skripsi Fakultas Ekonomi Universitas Airlangga.

Ferdinan, Hery. 2011. Pengaruh Pengeluaran Pemerintah, PDRB, dan Upah Riil terhadap Penyerapan Tenaga Kerja ,(online),

(http://repository.ipb.ac.id), diakses pada tanggal 12 Desember 2015). Skripsi. IPB

Handoko, Hani T. 1985. Manajemen Personalia dan Sumber Daya Manusia. Yogyakarta: Liberty.

Laporan Perkembangan Keuangan Syariah (LPKS) Tahun 2013. 2013. (online), (www.ojk.go.id, diakses pada tanggal 1 Desember 2015)

Iswanto. 2013. Pengaruh Efektivitas dan Efisiensi Pengelolaan Keuangan Daerah serta Sistem Pengendalian Intern Terhadap Keandalan Laporan Keuangan Pemerintah Daerah (Studi Empiris Pada Pemerintah Kabupaten/Kota Se-Indonesia). Tesis. Program Pascasarjana IImu Akuntansi. Universitas Lampung.

Mankiw, N. Gregory. 2012. Principles of Macroeconomics. Third Edition. Thomson South Western .

Otoritas Jasa Keuangan. 2014. Statistik Perbankan Syariah, (online), www.ojk.go.id, diakses pada tanggal 28 Februari 2016.

2015. Statistik Perbankan Syariah, (online), www.ojk.go.id, diakses pada tanggal 28 Februari 2016.

Prasetyantoko, A. 2008. Arsitektur Baru Ekonomi Global. Jakarta: Elex Media Computindo

Putra, Riky Eka. 2012. Pengaruh Nilai Investasi, Nilai Upah, dan Nilai Produksi terhadap Penyerapan Tenaga Kerja pada Industri Mebel (Studi Kasus di Kecamatan Pedurungan) Kota Semarang Provinsi Jawa Tengah. Economic Development Analysis Journal(EDAJ), Vol 1 No:2, Hal:125-136 
Kasmiarno, et al/Jurnal Ekonomi Syariah Teori dan Terapan Vol. 3 No. 10 Oktober 2016: 816-828; ANALISIS PENGARUH INDIKATOR EKONOMI DAN KINERJA PERBANKAN SYARIAH TERHADAP PENYERAPAN TENAGA KERJA PADA PERBANKAN SYARIAH DI INDONESIA TAHUN 2008-2014)

Putra, Candra Perdana. 2013. Pengaruh Jumlah Perusahaan, nilai Investasi PMDN, Dan Nilai Produksi Terhadap Penyerapan Tenaga Kerja Pada Industri Kecil Di Kota Madiun Tahun 2007 - 2011. Skripsi. Fakultas Ekonomi dan Bisnis Universitas Airlangga.

Salvatore, Dominick. 1987. International Economics. Second Edition. New york: Macmillan Publishing Company.

Samuelson, Paul A. 1997. Ekonomi, Jilid I dan Jilid II. Jakarta: Erlangga.

Simanjuntak, Payaman J.1998. Pengantar Ekonomi Sumber Daya Manusia. Jakarta: Lembaga Penerbit Fakultas Ekonomi Universitas Indonesia.

Setiawan, Adi. 2009. Analisis Pengaruh Faktor Makroekonomi, Pangsa Pasar, dan Karakteristik Bank terhadap Profitabilitas Bank Syariah. Tesis. Universitas Diponegoro.

Sukirno, Sadono. 1985. Ekonomi Pembangunan. Jakarta: Lembaga Penerbit Fakultas Ekonomi UI dengan Bina Grafika.

Sumarsono, Sony. 2003. Ekonomi Manajemen Sumber Daya Manusia (SDM) dan Ketenagakerjaan. Yogyakarta : Graha ilmu

Suparmoko, M. 2002. Ekonomi Publik: Untuk Keuangan dan Pembangunan Daerah. Yogyakarta: Andi

Wahyudiantoro, Ony. 2010. Penyerapan Angkatan Kerja pada Sektor Usaha Kecil Menengah (UKM) di Indonesia Tahun 2003-2007. Skripsi. Fakultas Ekonomi dan Bisnis Universitas Airlangga.
Widarjono, Agus. 2005. Ekonometrika Pengantar dan Aplikasinya. Jakarta:EKONISIA

Woyanti, Nenik dan Dian Yanuwardani W. 2009. Analisis Pengaruh Faktor Ekonomi terhadap Penyerapan Tenaga Kerja pada Industri Kecil Tempe di Kota Semarang. Jurnal Media Ekonomi dan Manajemen (JMDEM), Vol 20 No.2, Hal. 190-201 